\title{
WHY BE JIHADIST? PUBLIC INTELLECTUALS' BLIND SPOT FOR ISLAMIST TERRORISM ${ }^{1}$
}

\author{
Peter Demant ${ }^{2}$
}

\begin{abstract}
Western publicintellectuals, in particular those on the Left, have sometimes relativized terrorism, including jihadist attacks perpetuated by a small minority of Muslims. This article discusses recent contributions of intellectuals to analysis of, and strategies to cope with, terrorism. We classify intellectual positions along two axes, one corresponding to the "classical" Left-Right spectrum and the other going from universalism to relativism. This yields 4 quadrants, viz. roughly the (Marxist-anarchist) Leftist and the liberal versions of universalism, and the postmodernist-multiculturalist and conservativeculturalist wings of relativism. Each quadrant has its specific explanation and answer to the challenge of jihadi terrorism, however, while the former two find themselves on the defense, the latter pair is growing. Both Marxists and postmodernists tend to blame world capitalism. But while the universalistic Left shares with liberal democrats a search for universally transformative structural change, relativists call foremost for changes in attitude, with Leftwing multiculturalism blaming the West and arguing for tolerance of subaltern Islam (sometimes including its violent expressions), while the culturalist Right blames Islam and calls for ("Islamophobic") cultural protectionism.

However, thus far no effective answer to jihadism seems to have emerged, a lacuna which may be imputed to a blind spot common to most intellectual positions: reluctance to address the
\end{abstract}

\footnotetext{
${ }^{1}$ Paper presented at the International Conference on Terrorism [Conferência Internacional sobre Terrorismo: Religiões, Intelectuais e Mídias: Posições diante do Terrorismo] of the Centro Cultural Brasil-Turquia and Faculdade Cásper Líbero, São Paulo, 8-9 March 2016.

Note on terminology: I use the terms terrorism for the phenomenon of violence inflicted by non-state perpetrators against noncombatant citizens for the sake of some ideal. I differentiate Islam and Muslim denoting the religion (Islam) and Islamic civilization from the concepts Islamism and Islamist (islamiyya, synonymous with Islamic fundamentalism) which designates an ideology that stems from a certain political reading of this religion. Jihadism is a tendency within Islam. The Islamic State (al-Dawla al-Islamiyya, IS) refers to the group formerly called Islamic State in Iraq and the Levant (also known as ISIS or Da'esh, the Arabic acronym for al-Dawlah al-Islamiyah fi ' l-'Irāq wal-sham), which as of this writing controls an independent territory between Iraq and Syria. Using the name this group gives itself does not imply any judgment on its Islamic quality, no more than calling for example Israel the "Jewish state" would imply acceptance of the specific view of Judaism of the Israeli leadership.

${ }^{2}$ Prof. Dr. Peter Robert Demant is historian and observer of International Relations, specializing in Middle East issues, the Muslim world and Islam-West relations. Ph.D. in Modern and Contemporary History at Amsterdam University (1988), and "Livre-Docência" in Contemporary History, University of São Paulo USP (2007). Currently associate professor at USP History Department, also lecturing at the Institute of International Relations (IRI-USP), Demant is also coordinator of the Asian Studies Laboratory (LEA-USP) and responsible for its Middle East and Islamic World Working Group (GTOMMM).
} 
sources of attraction that seduce some people into terrorist activity. The article compares a few recent attempts at understanding these sources, and concludes that their common denominator is a crisis of belonging and transcendence of the West itself: addressing and responding to this social and ideological crisis is a task for the West's public intellectuals, and precondition for effectively countering terrorism. atribuída a um ponto cego comum à maioria das posições intelectuais: a relutância em lidar com as causas que atraem algumas pessoas ao terrorismo. Este artigo compara algumas tentativas recentes de entender estas causas e conclui que seu denominador comum é uma crise de pertencimento e transcendência do próprio ocidente; lidar e responder a esta crise social e ideológica é tarefa dos intelectuais ocidentais públicos e precondição para efetivamente atacar o problema do terrorismo.

"Scarcely a mass-murdering dictator of the twentieth century was without his intellectual supporters, not simply in his own country, but also in foreign democracies, where people were free to say whatever they wished". ${ }^{3}$ Does this damning sentence at the opening of Intellectuals and Society (2009) of libertarian American economist Thomas Sowell also apply to the attitudes of Western "opinion leaders" to terrorism, jihadist in particular? And if so, why? Do better alternatives exist? This is the focus of the following critical reflection on intellectual reactions in the West to the rising curve of jihadi terrorism of the last years.

Immediately after the January 2015 attacks against Charlie Hebdo, millions of stupefied and scandalized French marched in massive demonstrations against terrorism. Sociologist Emmanuel Todd, however, deciphered and delegitimized these acts as an Islamophobic manifestation of the conservative fraction of France. ${ }^{4}$ Noam Chomsky, the world's most quotedlive intellectual reacted to the terrorist acts exclaiming that "Contrary to the eloquent pronouncements, it is not the case that "Terrorism is terrorism. There's no two ways about it. "There definitely are two ways about it: theirs versus ours"5 If we look at other recent attacks, we find more disconcerting examples of usually Leftist, public intellectuals, who have relativized attacks or considered them "understandable". On 9/11 2001, al-Qaeda's attacks on New York's Twin Towers horrified humankind. For Chomsky, however, the real terrorists were the US whose wickedness had provoked this just punishment. Philosopher Slavoj Zizek did not go as far as praising Osama bin Laden but considered fundamentalism and global capitalism as two sides of one same "real". Philosopher Jean Baudrillard actually celebrated the attack as the symbolic reaction to a commodified capitalist world. Playwright Harold Pinter and novelists Norman Mailer and Arundhati Roy were among several intellectuals who expressed some understanding for the act of terror. ${ }^{6}$ But the association of a certain intelligentsia with political violence

\footnotetext{
${ }^{3}$ Sowell (2009) p. 11.

${ }^{4}$ Todd (2015) was immediately criticized by Alain Finkielkraut and other French public intellectuals.

${ }^{5}$ Chomsky (2015)

${ }^{6}$ Baudrillard (2003); Zizek 2002; https://en.wikiquote.org/wiki/Harold_Pinter http://www.telegraph. co.uk/comment/personal-view/3585148/The-American-administration-is-a-bloodthirsty-wild-animal. html; http://www.newenglishreview.org/Ibn_Warraq/Apologists_of_Totalitarianism\%3A_From_Commu-
} 
started long before 9/11. Libertarian ("autonomist") Marxist Antonio Negri, accused of responsibility for the terrorist acts of the Red Brigades group in the 1970s, spent the years from 1997 to 2003 in an Italian prison, where he wrote with Michael Hardt his book Empire. The link of few famous public intellectuals with terrorism goes beyond this and is older. Michel Foucault met Khomeini and in 1978 expressed sympathy for the Islamic Revolution in Iran. ${ }^{7}$ Sartre praised in his 1961 preface to Frantz Fanon's The Wretched of the Earth the author's call for "cathartic" anticolonial violence in the Algerian war with the words. "In first phase of the revolt on has to kill: to shoot down a European is to kill two birds with a stone, eliminating at once an oppressor and an oppressed; what is left is a dead man and a free man." ${ }^{8}$ In this context it may not be superfluous to recall that Martin Heidegger, the philosopher who most influenced the existentialist Sartre and the postmodernists such as Foucault, had in the 1930s been an active supporter of the Nazis; even after World War II, he never really repented. ${ }^{9}$

We should perhaps not exaggerate such expressions, all of the Left, which might be read as reflecting a pro-terrorist trend. On the one hand, such voices are a minority compared to those others that oppose to violence and favor solidarity with the victims. On the other, one may find completely different intellectual lineages that also inspired terrorist acts. In 2011, the Norwegian terrorist Anders Breivik pointed among others, at anti-Islamic intellectuals Robert Spencer and Ayaan Hirsi Ali as inspirations of his massacre, supposedly in protest against multiculturalism. ${ }^{10}$

Even so, the silence of many intellectuals in the aftermath of 9/11 was perhaps worse than any words. I want to address here a complex connection. Have public intellectuals helped us to understand terrorism, and in particular Islamic and jihadist terrorism? Have certain "critical" positions contributed to legitimizing it? Do the contributions of public intellectuals help us to deal with terrorism and develop a strategy against it?

\section{What and who are the public intellectuals?}

To understand how "public intellectuals" might fit into a typology of responses to today's grand debates, we must first of all define them. I define public intellectuals here as our interpreters of current crises. They are philosophers, sociologists, historians, journalists,

nism_to_Islam,_Part_IV/; http://www.theguardian.com/world/2001/sep/29/september11.afghanistan

${ }^{7}$ Afary and Anderson (2005).

8 “Car, en le premier temps de la révolte, il faut tuer: abattre un Européen c'est faire d'une pierre deux coups, supprimer en même temps un oppresseur et un opprimé: restent un homme mort et un homme libre (...).": Fanon p. 29.

${ }^{9}$ Cf. Farias (1989) e Lilla (2001) pp. 1-45. For the prolongation of the Heidegger question in French philosophy, cf. Richard Wolin, "French Heidegger Wars". in: Wolin (1988), pp. 271-300.

${ }^{10}$ In his manifest-compendium that justifies his terrorist act, Breivik quotes admiringly several intellectuals such as Robert Spencer, Pamela Geller, Ayaan Hirsi Ali, Keith Windschuttle, and Patrick Buchanan: Berwick (2011) (Berwick is Anders Breivik's pseudonym). 
novelists and others who do not limit themselves to their specialty, but express themselves in the public arena, and take part in, and shape the debate about the big issues of our world ("opinion leaders"). In the past century those topics might have been the Dreyfus process, the Vietnam war, or the question of Stalinism. Today the agenda is dominated by the question of Islam, and its difficulties or possibilities to coexist with and integrate in the West, and by the challenge of understanding and dealing with Islamist... and Islamophobic violence and terrorism. An important feature is that public intellectuals are (almost by definition) "irresponsible": despite their prestige among the educated public (also by definition) and the fact that they have the ear of political decision makers, they seldom have to answer for the consequences of their words. Doctors, pilots, or generals cannot afford this luxury of irresponsibility. Nor, incidentally, researchers, results of whose efforts are usually controlled by external bodies. In theory public intellectuals, even those who criticize reason or the Enlightenment, operate within a shared rationalist discourse. The kind of modern "ideas producer" first emerged in France in the late 19th century. Until World War II, they were mostly novelists: Zola, Gide, Malraux, etc. Next Sartre and Camus introduced the philosopher as public intellectual. And in more recent decades we have to deal with Althusser, Baudrillard, Derrida, and other stylistically challenged university professors. However, worse than this recent academization of public intellectuals is the fact that - since Lyotard proclaimed the death of metanarratives - we suffer from a lack of innovative global analyses. The qualitative decline of the public intellectual, identified and deplored twenty years ago by Richard Posner, seems justified. ${ }^{11}$

Public intellectuals are generalists. They may or may not be also experts or researchers or intellectuals of another other kind, i.e. whose products are not addressed to the general public but to other specialists. The distinction is significant. It is thanks to the work of researchers that we know how many Muslim women opt for wearing the burqa. But we owe to philosopher and public intellectual Martha Nussbaum an argument in favor of the freedom of dress of Muslim women. Researchers (journalists, psychologists...) have discovered that jihadist terrorists are - unlike the opinion of certain statesmen - neither nihilists nor psychopaths. But public intellectuals such as Samuel Huntington or Jean Baudrillard or John Gray then articulate opinions about how to understand the jihadists' acts - e.g. how 9/11 fits in the clash of civilizations, or creates an absolute event made inevitable by the expansion of capitalist globalization, or else symbolizes the aporia of modernity. ${ }^{12}$ Henceforth I will use the generic term "intellectual" for public intellectuals the specific subject of this article.

To establish a list of such voices may be somewhat arbitrary and difficult, but is not impossible. Confining ourselves here to Western intellectuals (or to those writing in or

${ }^{11}$ Cf. Posner (2001). About the academization of intellectuals, cf. Jacoby (2000) e Sowell (2009).

${ }^{12}$ About the burqa cf. Nussbaum (2010); Huntington (1993) and his subsequent homonymous book of 1996. Baudrillard (2003); Gray (2005). 
regularly translated into English or French and for a primarily Western audience) ${ }^{13}$ and excluding long dead intellectuals, and those who are foremost religious or political rather than intellectual leaders (e.g. Pope Benedict XVI, or Henry Kissinger in the 1969-1977 era when he was US Secretary of State), and basing ourselves on the polls of a couple of widely read magazines and sites, one list of the ten most important intellectuals might look this (not necessarily by quality or originality of arguments but by popularity, and in order of public relevance): ${ }^{14}$

1. Noam Chomsky
2 Michel Foucault
3 Jürgen Habermas
4 Edward Said
5 Slavoj Zizek
6 Samuel Huntington
7 Francis Fukuyama
8 Salman Rushdie
9 Alain Finkielkraut
10 Antonio Negri

This list is of course impressionistic and it would not be hard to add other names. Nor does it reflect any preference for specific (by the way, incompatible) ideas, and yours would no doubt look different. But it would probably be possible to agree on a list of twenty or thirty of the most notable and influential names. Even so, it is obvious that not all intellectuals express themselves about every issue. If we leave aside a larger number of relatively little-known specialists, the group of public intellectuals that actively molds the debate on Islamic terrorism is not numerous.

Regardless of the composition of such a list (and the method for arriving at it), it seems clear that the public discussion of such a crucial political, security and ideological issue as jihadist terrorism is largely dominated by a relatively small number of famous voices. ${ }^{15}$

\footnotetext{
${ }^{13}$ Despite globalization many intellectual discourses still predominantly circulate within the orbit of specific civilizations and languages. Alexandr Dugin, Putin's Eurasianist apostle and perhaps the best known Russian public intellectual, is almost unknown outside Russia. Intellectuals writing in Chinese have little impact outside China. The same goes for most Islamic thinkers who write (even in English or French) for Muslim audiences, such as Yusuf al-Qaradawi, Fethullah Gülen, or Abdolkarim Soroush. Tariq Ramadan is one of the few exceptions.

${ }^{14}$ At the end of the $20^{\text {th }}$ century Posner published lists based on popularity by quotation. Prospect and Foreign Policy publish (since 2005 and 2009, respectively) annual lists based on reader preferences. But each list has its arbitrariness and has been the object of criticisms. Foucault, Huntington, and Said are no longer alive, and Chomsky, Negri, and Habermas are at an advanced age. Still they are among the most quoted intellectuals.

15 The following names spring to mind: Michael Walzer, Jacques Derrida, Judith Butler, Christopher Hitchens, Bruno Latour, Bernard-Henri Lévy, Bernard Lewis, Alain Badiou, John Gray, Jacques Derrida, Anthony Giddens, Charles Taylor, Immanuel Wallerstein, Emmanuel Todd, Niall Ferguson, Amartya Sen, Thomas Friedman, Fareed Zakaria, Ian Buruma, Robert Wright, Michel Houellebecq. Bassam Tibi, Philip Bobbitt, Marcel Gauchet, Robert Fisk, Paul Berman, Anthony Giddens, Fareed Zakaria, Ian Buruma, Kwame Appiah, and Charles Taylor would be a few other obvious candidates. The (in)famous "list of Posner" of 546 public intellectuals based on ranking in the media and academic citations has been the object of fierce though not always honest criticism (cf. http://www.complete-review.com/quarterly/vol3/issue2/posner.htm), but re-
} 


\section{The four intellectual families}

Intellectuals like to debate and defend opposing views. How to classify them? The traditional classification of political and intellectual positions on a one-dimensional scale from Left to Center to Right may be challenged. ${ }^{16}$ To do justice to the complexity of the debate on e.g. terrorism, I propose to replace this diagram by a two-dimensional frame, one of its coordinates matching the classic Left/Right antinomy, and the other, the universalistic / particularistic-relativistic dimension.

The first coordinate would then go from anticapitalist and emancipatory positions which consider the status quo as intolerable and which believe in the malleability of social and international arrangements, to more defensive positions that consider current structures as either acceptable or the lesser evil, and view social arrangements as essentially immutable. The Left, "progressive", believes in transformation of the political and social status quo toward greater equality and emancipation of the oppressed or the excluded. The Right, "conservative", accepts inequalities as inevitable, and rejects extreme changes of the status quo. It is also possible to define the two poles as utopian and dystopian.

The second axis distributes opinions on a scale that ranges from universalistic, generally accepting modernity, to relativistic and critical of modernity. The modernist accepts the existence of objective truth, the (at least potential) rationality of the human being, and the possibility of progress. Its opposite rejects the possibility of objective and universally valid judgments and, instead of the narrative of progress, advocates respect for the insurmountable differences between human groups.

This produces the table below (each quadrant has affinity for a particular school of international relations)

mains a landmark. For the Foreign Policy list, cf. http://foreignpolicy.com/2008/05/15/top-100-public-intellectuals/.

${ }^{16}$ Obviously there are many other possibilities, e.g. combining the Left/Right axis with a second individualism/communalism coordinate; or with Hans Eysenck's mentality axis reaching from tough-mindedness to tender-mindedness, and its variation in the "Nolan diagram"; or with an authoritarianism/democracy spectrum; in Ronald Inglehart 's World Values Survey, a biaxial system crosses one coordinate from traditionalism to secularism with another ranging from "survivalism" to self-expression. 


\begin{tabular}{|c|c|c|}
\hline \multirow{2}{*}{$\begin{array}{l}\text { POLITICAL POSITIONS OF } \\
\text { MAIN INTELLECTUAL } \\
\text { CURRENTS }\end{array}$} & $\begin{array}{c}\text { LEFT } \\
\text { (utopian) }\end{array}$ & $\begin{array}{l}\text { CENTER / RIGHT } \\
\text { (dystopian) }\end{array}$ \\
\hline & $\begin{array}{l}\text { Emancipation, extension of rights. } \\
\text { Anticapitalist. Human nature and } \\
\text { social reality are malleable, } \\
\text { status quo is intolerable }\end{array}$ & $\begin{array}{l}\text { Protection of ac-quired rights. Not } \\
\text { anticapitalist. } \\
\text { Human nature and social reality are } \\
\text { immutable. } \\
\text { status quo = lesser evil }\end{array}$ \\
\hline $\begin{array}{l}\text { UNIVERSALISM/MODERNISM } \\
\text { (positivist) }\end{array}$ & $\begin{array}{l}\text { 1. Marxism } \\
\text { \& anarchism } \\
\text { (IR: marxism) }\end{array}$ & $\begin{array}{l}\text { 3. liberal democracy \& neoconser- } \\
\text { vatives } \\
\text { (IR: idealism) }\end{array}$ \\
\hline $\begin{array}{l}\text { RELATIVISM/PARTICULARISM } \\
\text { ANTIMODERNISM } \\
\text { (subjectivist) }\end{array}$ & $\begin{array}{l}\text { 2. Pomo (post-modernism) } \\
\text { (IR: constructivism) }\end{array}$ & $\begin{array}{l}\text { 4. conservatism-culturalism } \\
\text { (IR: realism) }\end{array}$ \\
\hline
\end{tabular}

(IR: equivalent International Relations theory)

A rapid (and necessarily schematic) characterization will permit us to contextualize how each quadrant relates to terrorism.

1. the first quadrant 1 , which includes Marxists and anarchists, constituted up to half a century ago the alternative to the status quo, but has lost much influence due to a number of well-known factors: the transformation of capitalism into the welfare state, with consumerism leading to the concomitant loss of the proletariat as the revolutionary subject; the unimaginable human cost of the construction of communism in the USSR, China and elsewhere; their economic failures and totalitarian policies; anti-positivist trends in science; and the implosion of the Soviet system at the end of the Cold War. However, no less serious have been, intellectually, the postures of denial from Sartre to Chomsky, of the gulag and the genocides. For many in the West, the collapse of communism in the 1980s and 1990s delegitimized the Marxist project, as well as several related projects that tried to combine nationalism with socialism. Part of the intellectuals migrated to more centrist or even rightist anti-totalitarian positions (such as the neo-conservatives in the US and the "new philosophers" in France). Another part migrated to relativist positions. A universalistic Left survives i.a. in today's alterglobalist movement. And there is still a rather fertile intellectual production - protagonists include Negri, Chomsky, Alain Badiou, and Immanuel Wallerstein.

2. Quadrant 2 includes postmodernists and multiculturalists. As anti-essentialists they deny the objective existence of social categories such as race, nation, gender, sexual orientation, which they decipher as socially constructed. The emphasis is on respect for diversity and otherness, even if some of the to-be-emancipated non- 
Western or subaltern groups have customs that may look exotic to the Western elite (from cannibalism to the stoning of adulterers). In fact, racism, slavery, and genocides perpetrated by a West inspired by dichotomous Orientalist worldviews have generated a "post-colonial guilt" that supposedly invalidates any liberal protests and justifies "politically correct" censorship. Intellectuals in this quadrant tend to doubt the primacy of reason, responsible not so much for freedom as for genocide and totalitarianism, and deconstruct many categories as mere, unstable or perhaps nonexistent, social constructs. Foucault, Jacques Derrida, François Lyotard, Said, Zizek, Judith Butler and Bruno Latour are the prime references, though (according to Mark Lilla) stronger in attitude than in argument. ${ }^{17}$ The weakness of this current lies in its difficulty to translate abstract radical theory in coherent collective policies, which has led critics such as Richard Wolin to assume a subterranean affinity between this Left and the Nietzschean or Heideggerian Right that supposedly inspires it. Despite the criticism, the protagonists keep their strength, and in many academic circles, antistatus quo "pomo" currents have remained hegemonic.

3. The third quadrant are the universalist and liberal internationalists, including supporters of global exportation of democracy and human rights: Michael Walzer, Fukuyama, Bernard-Henri Lévy, Vaclav Havel, Michael Ignatieff, Alain Finkielkraut, and Thomas Sowell and (though more qualifiedly) Habermas and Anthony Giddens, both of whom have been called by critics "the last modernist"). ${ }^{18}$ Although philosophically important differences divide them, what is relevant here are their convergent public postures. This universalistic current has recently been weakened by factors such as its association with neo-liberal globalization, the failures of US interventions in the Islamic world, and popular reticence (or fatigue) to confront autocracies. In the aftermath of the third stage of democratic expansion, ${ }^{19}$ we are today experiencing a reflux: in the old Western powers, democracy has generated depoliticization, while in the plural and segmented societies of Eastern Europe, Asia, Africa and Latin America, new democracies have rarely been able to transform ingrained conflict mentalities of zero-sum and winner-takes-all.

4. Quadrant 4 includes a variety of relativists who defend the status quo: culturalists insisting in the incommensurability of civilizations and religions, conservatives who seek to defend their nation, race or social norms against supposed invasions of revolutionaries, "superficial" globalist "levelers", or migrants carriers of alien cultures. They are the champions of fixed identities (state, nation, family, civilization and others). While this may

\footnotetext{
17 The historian of ideas Mark Lilla observes that “... postmodernism is long on attitude and short on argument" (Lilla 2001, p. 163).

${ }^{18}$ Mestrovic (1998).

${ }^{19}$ Huntington (1991).
} 


\section{ensaio}

not sound relativistic, in the end their insistence on the uniqueness if not superiority of their own group dilutes whatever universal values they proclaim: the primacy of one's heritage cannot be reduced to any universal essence. Again, this is a heterogeneous group where communitarians and family values advocates, nationalists, isolationists and Eurasianists rub shoulders with anti-Semites and Islamophobes, ecologists with climate change deniers, and traditionalist Christians with adherents of various esoteric sects. While pre-World War II racism is rare today, the New Right has replaced the old category "race" by that of an almost hereditary and no less closed "culture". This current is the only one that is indubitably growing, due to the perception in many places of an external cultural attack, either by supranational bureaucracies or by immigrants. To address these threats, Marxist and liberal as well as postmodern and postcolonial intellectuals, are considered at best naive and in the worst case, traitors. This current has populist and anti-intellectualistic fringes, and may even inspire their own violent extremists, but has also included influential intellectuals such as Louis Pauwels, William Buckley, John Gray, Samuel Huntington and Robert Spencer.

Like any classification, also this one is vulnerable to a criticism of forced analogies and schematism. Against the above proposed division one may, for example, raise the following objections: (1) to join in the same category centrists and rightists would not please either. My criterion here was to separate those intellectuals whose opposition to the status quo advocacy of revolutionary (implicitly violent) transformation from those who reject it. But of course there exist also violent counterrevolutionary conservative voices. ${ }^{20}$ (2) universalism does not always overlap with modernism nor relativism with antimodernism. ${ }^{21}$ (3) within each category there are major differences; ${ }^{22}$ (4) Some authors would fit into more than one category, others none; ${ }^{23}$ and finally (5) our categorization may be too culturally specific. Islamists are by definition universalists, yet politically they

\footnotetext{
${ }^{20}$ Frauke Petry, leader of the Far Right party Alternative für Deutschland (AfD, Alternative for Germany) in March 2016 urged the police to shoot refugees trying to enter illegally in Germany: "Frauke Petry, the new face of the extreme right in Germany." In: Carta Capital 11-3-2016. http://www.cartacapital.com.br/revista/888/hitler-de-saias.

${ }^{21}$ E.g. Michael Walzer is doubtlessly a modernist yet he embraces certain relativistic positions: for him, ultimately every human community is committed to their own values which instill meaning into the actions and lives of its members; Ian Buruma was criticized for his supposed cultural relativism, though he is certainly not anti-modern.

22 Samuel Huntington and Alexandr Dugin are both defensive culturalist conservatives, but beyond that, their positions differ strongly, with Huntington a defender of democracy and Dugin bordering on fascism. Habermas and Sowell can both with some effort be made to fit in the same quadrant 3, yet their "liberalism" has diametrically opposed origins.

${ }^{23}$ The modernist Habermas, although no longer a classical Marxist, has his roots in the Frankfurt tradition. Zizek mixes Marxist concepts with Lacanian ones. There are crossover cases between quadrants 1 and 2, 1 and 3, 2 and 4, and 3 and 4: only between 2 and 3 there do not seem to be occur links. Several novelists as well as intellectuals whose interventions focus on other controversial issues (such as evolution vs. creationism, or religion vs. atheism) are also difficult to accommodate in a particular quadrant (e.g. Paulo Coelho, or Richard Dawkins).
} 
are often allies of progressive relativists (in the question of imperialism) or conservative relativists (in the women's question). My rationale for keeping to our diagram is that it organizes opinions in a succinct and broadly usable way and accounts for most cases. For the purposes of this article, that seems to be enough.

We conclude that the two universalistic currents, the Marxist and the liberal-democratic are today in decline or under attack, while the two relativistic wings, the postmodern/ post-colonial Left and the cultural-protectionist Right, have maintained themselves, or grown.

That gives us already a clue as to the ongoing exacerbation of the terrorism issue: while the postmodern current tends to excuse jihadism, its nativist, anti-immigrant and Islamophobic counterpart of the "clash of civilizations" is creating arguments which the jihadis then use against themselves, thus provoking more terrorism.

\section{What is terrorism?}

It is sometimes observed that "one person's terrorist is the freedom fighter of the other." It would all depend on one's perspective. I reject such facile relativism which confounds means and ends. After all, every terrorist considers himself as someone who defends a noble cause; yet do noble causes need bloodbaths of innocent victims for their defense? All the same, terrorism is a complex concept. One researcher counted over one hundred definitions. ${ }^{24}$ For the purposes of the present argument I define terrorism by the combination of the following three criteria:

(1) use of violence against non-combatants and other defenseless people

(2) in favor of a political-ideological goal

(3) by an actor opposed to current power holders

This simple definition allows us to pin down which violent acts are or are not terrorism.

Ad (1) violence against noncombatants: according to this distinction, Lebanese Hezbollah attacks against Israeli soldiers is not terrorism, but a Palestinian suicide bomber from Hamas who explodes twenty Israeli citizens in a nightclub in Tel Aviv is a terrorist;

\footnotetext{
${ }^{24}$ Alex Schmid, the Dutch-Swiss Nestor of terrorism studies, analyzed more than 100 definitions in the literature, and comes the following "consensual academic" definition: "Terrorism is an anxiety-inspiring method of repeated violent action, employed by (semi-) clandestine individual, group or state actors, for idiosyncratic, criminal or political reasons, whereby - in contrast to assassination - the direct targets of violence are not the main targets. The immediate human victims of violence are generally chosen randomly (targets of opportunity) or selectively (representative or symbolic targets) from a target population, and serve as message generators. Threat- and violence-based communication processes between terrorist (organization), (imperilled) victims, and main targets are used to manipulate the main target (audience(s)), turning it into a target of terror, a target of demands, or a target of attention, depending on whether intimidation, coercion, or propaganda is primarily sought": Schmid 1988. Cf. http://web.archive.org/web/20070527145632/ and http://www.unodc.org/unodc/terrorism_definitions.html. Cf. Hoffman (1998), p. 39.
} 
Ad (2) political and ideological goal: a psychopath who kills ten students at a US university is not a terrorist, but Anders Breivik who massacred in 201165 young socialists on a Norwegian island in protest against multiculturalism is a terrorist. Just as Major Nidal Hassan, who killed thirteen US soldiers at a military base in 2009 for jihadists reasons. Ad (3) the terrorist actor acts in opposition to power: this allows us to disentangle terrorism from "state terrorism," a confusion introduced by Chomsky. ${ }^{25}$ When Saddam Hussein massacred 80,000 Kurds in the 80ies, he was the Iraqi dictator: this was state terrorism. When President Obama orders the execution of Osama bin Laden or bombs Islamic State offices in their capital Raqqa, this may or may not be an act of war, and it may or may not be state terrorism; but it is certainly not the terrorism an oppositional actor. Terrorism is, as its early theorists in 19th-century Russia reasoned, "propaganda of the deed": the violent act would force a public debate of the terrorist's cause and thus advance it. It is not only an attack but also a communication albeit one that transcends verbal or written persuasion.

Today the vast majority of terrorist attacks around the world have an Islamist motive. ${ }^{26}$ Therefore it is the jihadist type of terrorism that occupies most attention of intellectuals. Unfortunately, the fifteen years old maxim of Middle East specialist Bernard Lewis is still

25 “Chomsky says US is world's biggest terrorist." Euronews 17-4-2015: http://www.euronews. com/2015/04/17/chomsky-says-us-is-world-s-biggest-terrorist/. Cf. Chomsky and Herman (1979).

${ }^{26}$ The question of the proportion of Islamist attacks within contemporary terrorism has itself become controversial and politicized. Some publications claim that the record shows Muslims account only for a tiny proportion of all terrorist acts (fewer Muslim than Jewish terrorists acts would occur), and that most attacks are of a nationalistic (Basque, Corsican, Kurdish etc.) nature or else (according to other sources) come from the extreme Right. Disproportionate public emphasis on Muslim violence must therefore be the result of media bias (if not of more obscure conspiratorial forces) or, in a word, of Islamophobia. Anti-Islamic think tanks and sites obviously promote an opposite reading. This is not the place for a thorough discussion of the subject, but some observations are in order. These tend to reinforce a critical interpretation of Islam. Statistics can be manipulated by chronological starting or cutting-off point (for example, if one starts counting from the 1970s, the percentage of Islamist attacks decreases, because they only became more numerous after September 11, 2001), by the definition used (is an attack only considered terrorist if it results in dead? Does one count the number of attacks or of perpetrators or victims?), and by other considerations. According to a FBI count, a huge part of attacks in the US did not cause any casualties, and attacks with Islamist reason constitute a tiny portion: https://www.fbi.gov/stats-services/publications/terrorism-2002-2005/ terror02_05.pdf. But the FBI excludes terrorism outside the US territory, and includes in its list not only all attempts using bombs, but also kidnappings and politically motivated bank robberies, vandalism, and attacks on circus wagons to free animals etc. Once one counts the number of victims, however, the Islamist attacks predominate even in the US. Cf. "All Terrorists are Muslims...Except the 94\% that aren't." in: Loonwatch 20-1-2010 http://www.loonwatch.com/2010/01/not-all-terrorists-are-muslims/; "The Myth of the Non-Muslim Terrorist." in: http://www.thereligionofpeace.com/pages/articles/loonwatch-94-percent.aspx; Dean Obeidallah, "Are All Terrorists Muslims? It's Not Even Close” (14-1-2015), in: http://www.thedailybeast.com/ articles/2015/01/14/are-all-terrorists-muslims-it-s-not-even-close.html.

But the US has historically been spared by terrorism and - except for the outlier of 9/11 - victims of "normal " murders are far more numerous. On a global scale, however, the proportion of deadly and injured victims of Islamist attacks is huge, growing, and undeniable. According to a recent study by Yoram Schweitzer of the Institute for National Security Studies at Tel Aviv University, in 2015 alone 99\% of attacks by suicide bombers (adding 4,370 dead) were motivated by Islamism: Avi Issacharoff, “450 of 452 suicide attacks in 2015 were by Muslim extremists, study shows". in: http:/www.timesofisrael.com/450-of-452-suicide-attacks-in-2015-were-by-muslimextremists-study-shows/.

More detailed data on international terrorism may be consulted i.a. at the Global Terrorism Database of University of Maryland: http://www.start.umd.edu/gtd/. 
pertinent: although only a small percentage of Muslims support terrorism, most terrorists are Muslims. ${ }^{27}$ In spite of certain "optical errors" that may exaggerate the impact of jihadism, the attention given to it is not fortuitous.

In fact, jihadism displays a rising curve of deadly attacks. The vast majority of its victims, incidentally, are not Westerners but other Muslims. The Islamic State, the angry son of "father" al-Qaeda may not be the only jihadist organization with a universal program, but at present it is doubtlessly the most successful and dangerous one.

Obviously our definition reaches its limit when a terrorist organization is at the same time also a state: such is the case of the Islamic State, which is in open war against its neighbors and against all states in the world! When a suicide bomber kills 40 Shiites at a funeral in Baghdad (an almost daily occurrence that does not even enters the news anymore...) or over 100 in Paris (this one still calling attention) and the outrages are claimed by the Islamic State, it is hard to define whether it is terrorism or a military attack. However, as such acts are committed by local (Iraqi, French, Belgians and other) supporters on behalf of IS, we will for now consider them as terrorism.

\section{THE INTELLECTUAL QUADRANTS FACE TERRORISM}

\begin{tabular}{|l|l|l|}
\hline \multicolumn{1}{|c|}{$\begin{array}{c}\text { REACTIONS TO JI-HADIST } \\
\text { TERRORISM }\end{array}$} & \multicolumn{1}{|c|}{ LEFT } & \multicolumn{1}{c|}{ CENTER-RIGHT } \\
\hline $\begin{array}{l}\text { UNIVERSALISTIC } \\
\text { MODERNIST }\end{array}$ & $\begin{array}{l}\text { MARXISTS } \\
\text { "imperialism is worse". Capitalism } \\
\text { is guilty } \\
\text { - raising awareness }\end{array}$ & $\begin{array}{l}\text { POMO } \\
\text { MULTICULTI } \\
\text { "imperialism is worse " and the } \\
\text { West is guilty - } \\
\text { - from "respect otherness" to preven- } \\
\text { tive concessions to Islamist demands }\end{array}$ \\
\hline $\begin{array}{l}\text { RELATIVISTIC } \\
\text { ANTIMODERNIST }\end{array}$ & $\begin{array}{l}\text { LIBERAL DEMOCRATS } \\
\text { - dialogue ("misunderstandings are } \\
\text { responsible") } \\
\text { - from exporting democracy and } \\
\text { human rights to intervention in the } \\
\text { Middle East }\end{array}$ & $\begin{array}{l}\text { CONSERVATIVE } \\
\text { CULTURALISTS } \\
\text { "Islam is guilty", clash of civilizations } \\
\text { •cultural protectionism - Islamopho- } \\
\text { bia }\end{array}$ \\
\hline
\end{tabular}

Since the last decades, globalization with its many unresolved problems has produced a worsening of new crises. Among these, violent tendencies among various religious fundamentalisms stand out, including anti-Western and anti-modern Islamist terrorism. Since 9/11 in particular, Islamist-type violence has increasingly dominated discussions among both the general public and intellectuals. The French islamologist (and public intellectual) Olivier Roy has correctly remarked that most intellectual analyses fit into one of two categories: either anti-imperialist or anti-Islamic. Both narratives are incomplete. ${ }^{28}$

27 "Most Muslims are not fundamentalists, and most fundamentalists are not terrorists, but most present-day terrorists are Muslims and proudly identify themselves as such.": Lewis (2003), p. 137.

${ }^{28}$ Roy (2015). 
The analyses and assessments of terrorism stem from the a priori worldview of each quadrant. Thus for the relativistic New Left (quadrant 2), Islamist terrorism is the fault of the capitalist West. Some intellectuals openly defend in particular Palestinian terrorism. ${ }^{29}$ It is, however, more common to hear voices that relativize its importance, or accuse external factors, covering up or even justifying jihadism as distorted (but "understandable") counter reaction to the worse terror that would be Western imperialism (or the neoliberal order; or the deployment of pro-Western regimes in the Middle East; or Western support for Israel; or discrimination and "oppression" of Muslims in Western countries; or even Western cultural invasion of the Muslim world, disrespectful of the otherness of the nonWestern Muslim other, and through its Orientalist prism denying and undermining his authenticity). Ultimately the West is guilty and Islamist violence is its collateral and even logical effect: a wrong but understandable response to Western policies. In particular the US foreign policy in the Middle East, with its invasions of Afghanistan, Iraq, and Libya, is seen as the root cause. Chomsky, Said and Zizek, among others, exemplify this externalist and Islamophile explanation.

(Quadrant 1 Marxist analyses follow more or less the same track; public influence of its several theoreticians is, however, smaller).

The culturalist New Right (quadrant 4) defends the opposite, Islamophobic and internalist view that reduces jihadism to Islam itself ("there is no moderate Islam"), and accuses Islam per se of being conducive to terror. Terrorism then, becomes the expression of a supposed incompatibility between an (inherently "violent") Islam and "Western values"; and in accord with the clash of civilizations logic that violence shows its incompatibility with Western civilization. Alain Finkielkraut, Christopher Hitchens, and Ayaan Hirsi Ali are some of the voices tending in this direction.

Although its triumphalism has turned sour since Fukuyama proclaimed the end of history in 1989/1993, quadrant 3 universalists still maintain a long term optimistic outlook. They view jihadism as a malignant outgrowth of contemporary Islam's difficulty to integrate in modernity. It is also the only line that seeks to explain terrorism by polarization within Islam, which therefore divides Muslims into the "good" ones (those who can and should align with the universal liberal project) and the "baddies" (which allow themselves to be radicalized). ${ }^{30}$

\footnotetext{
${ }^{29}$ Zizek (2012) comes close to apologizing for terrorism in his preface to the book of Sophie Wahnich, In defense of the terror: Liberty and death in the French Revolution (2012). English-Canadian philosopher Ted Honderich (not especially postmodernist), though recognizing Israel's right of existence justifies the use of Palestinian suicide bombings as legitimate resistance to "neo-Zionism": Honderich (2003). Cf. his debate with Richard Wolin, “Are Suicide Bombings Morally Defensible?”. In: http://www.ucl.ac.uk/ uctytho/ Wolinhispiece.html, and Honderich's rejoinder in: http://www.ucl.ac.uk/ uctytho/Wolinmyreply.html.

${ }^{30}$ Mamdani (2005).
} 
Responses and strategies proposed by each line derive from of its analysis. A seen above, a significant portion of the intelligentsia is anti-capitalist and/or liberal and therefore has an emancipatory attitude of opposition to the status quo. This has historically been reflected in a certain support for (or "understanding" of) currents that used violence to destroy the system, including acts of guerrilla or terrorism, and sometimes support of illiberal tendencies in post-colonial states, including in the Muslim world.

The postmodern quadrant $\mathbf{2}$ advocates in general, "politically correct" concessions to Islamist demands, in the name of respect for the Muslim Other. These range from censorship of Mozart operas and of naked statues in museums to the removal of references to the Holocaust of the Jews in schools, to incorporation of shari'a in Western law, as well as demands for canceling the West's interventionist presence in the Middle East. A worrying aspect is the systematic non- attention to, or even rejection by the bien-pensant Leftist intelligentsia of moderate antijihadist analysis coming from progressive, critical and apostate Muslims. ${ }^{31}$

All this, however, does not directly address terrorism. In fact, beyond insisting in radical transformation of the West itself (or of the world) and in preventive compliance with generic Islamist pressures, postmodernist intellectuals have no specific strategy to face the demands of terrorist jihadis. And this would indeed impossible, as it would imply total surrender of the non-Islamic world (as well as of the majority of Muslims who reject jihadist theology and practice) to terrorists. That would soon lead to self-destruction of all Western intellectual tendencies, including that of the postmodernists themselves. One may question why this tolerance of a certain multiculturalist Left vis-à-vis a terrorism that has nothing progressive and reminds of fascism. But one cannot deny it. The caliph of the Islamic State probably views his naive supporters in the West just as Stalin viewed George Bernard Shaw, Romain Rolland or Sartre, who proclaimed the beauty of the Soviet system to Western audiences: "useful idiots."

For cultural protectionists (quadrant4) theanswer has to be defensive or confrontational. In general, they are pessimistic about Muslim intentions and the likelihood of reform within Islam, and advocate a strategy of anti-Islamic resistance. This ranges from demands for greater adaptation or even assimilation of Muslims living in the West, and for rejection of new refugees, to hate crimes and physical attacks. Such attitudes articulated by the ideologues of Rightwing parties are becoming increasingly popular in Europe and the USA. Ultimately, this may approach an opposite terrorism, e.g. burning houses of Muslim immigrants. Of course, this strategy of cultural and territorial closure also works in favor

\footnotetext{
${ }^{31}$ The most blatant cases are no doubt those of ex-Muslims (apostates) such as Ibn Warraq, Wafa Sultan, or Ayaan Hirsi Ali, but a similar treatment is meted out to critical Muslims such as Irshad Manji or Maajid Nawaz, and even to more mainstream but explicitly nonviolent and modernists such Abdullahi an-Na'im or Fethullah Gülen.
} 
of jihadis, because it only serves to deepen the alienation of Muslims around the world, thus encouraging radicalization.

It is interesting to observe how two tendencies that are both relativistic (albeit for opposite reasons) and both posturing as opposed to the "elite" of Western states, basically end up strengthening the object they want to control. Nonetheless between them they appear to dominate today's debates.

As against these quite consistent though counterproductive views, we encounter a vacuum in quadrant 3. In practical terms, intellectuals connected with this line propose confusing strategies. In principle they would prefer dialogical engagement with the Muslim world. Democratic and universalistic liberal intellectuals would insist on dialogue and negotiation and reject the use of violence as a method of conflict resolution, and are critical of both sides. Thus Walzer and Ignatieff would accept the use of terrorist means (as well as State counter-violence such as torture) only in the most extreme and restrictive circumstances, as a last means to rescue justice. ${ }^{32}$ Rushdie, Bassam Tibi and many other progressive Muslims are in favor of a reform within Islam.

In addition to its preference for dialogue, however, many in this quadrant are close to humanitarian interventionism or even to the neoconservative program of exporting democracy. Liberal democracy with its cortege of human and individual rights, international law and supranational institutions, is today the unofficial consensus of the international community. Not coincidentally have authors such as Fukuyama and "BHL" articulated military proposals against states or militant groups they view as facilitators of jihadism and/or human rights violators: Afghanistan, Iraq, Libya and now Syria and the Islamic State. Each new massacre committed by terrorists and each new humanitarian crisis posit again the dilemma between helping ("imperialist") or remaining indifferent ("cowardly inaction"). Now any intervention no matter how limited always and inevitably cause collateral civilian casualties, which stimulates anti-Western and possibly projihadi reactions. These and other paradoxical effects of interventions have worn down Western public support for new interventions: today anti-interventionist forces in the West effectively block any new intrusions in the Middle East sufficient to make a decisive military difference (assuming that a "military solution" to the jihadist challenge exists at all). True, recent jihadist attacks in the West (i.a. in Paris, November 2015) may erode public resistance to military action against the Islamic State and related groups. However, the beneficiary of the West's ideological "revival" is much more the Islamophobic Right than democratic universalists. In quadrant 3 , the result is paralysis!

Proponents of proactive human solidarity with victims of both terrorism and state terrorism (the famous R2P, the "responsibility to protect") are stuck in a stalemate between the failures of non-intervention (e.g. Rwanda 1996, and Syria today) and the calamities of intervention (Afghanistan 2001, Iraq 2003, Libya 2011).

\footnotetext{
${ }^{32}$ Walzer (1992) pp. 197-206, e Ignatieff (2004).
} 
Everyone agrees that a military defeat of the Islamic State would only be a battle, not victory in the war on terror. For this war to succeed, it would need to defeat not only current terrorists, but the growing attraction of jihadism among youth groups whose alienation from the society they live in will eventually constitute a mortal danger to all. Habermas, Fukuyama, Rushdie, Giddens, Ian Buruma, Robert Wright, Charles Taylor, and a host of other intellectuals of the third quadrant know and say that a solution cannot be achieved by violence but only by integration of those at risk of becoming future terrorists. Unfortunately, no one has yet articulated the new theory required for this task.

In brief, while there is no shortage of explanations, no intellectual current has so far offered a viable response to the jihadists. Most Western intellectuals point at large scale problems as causes for the deep crises in the Islamic world, the West, or between both. The existence of grave and worsening international and intercivilizational crises cannot be denied indeed, whether these are caused by incessant Western imperialism, permanent Western hostility to Islam, inherent hostility of Islam to the West, or still other factors. And yes, for some, religious terrorism might conceivably be one way of coping with crisis. Terrorism is, however, by no means necessarily the only or most probable choice. But which intellectual has shown why this is the road taken by those who do so? why it is growing in our days? to what outcomes, good or bad, may it lead - let alone what might be done to stop it? For alternatives exist and are actively pursued by many Muslims and non-Muslims. Yet even with a plethora of analyses attempting to identify structural or incidental factors that partly explain the phenomenon of jihadist terror, few public intellectuals address the sources of the attraction that jihadism succeeds in exercising. The focus on abstract causes (whether of a class, international, or cultural nature) of a situation propitious for the emergence of terror, and the failure to address the specific factors that lead ever more idealistic young people to embrace indeed jihadist terror, is the blind spot of our intellectuals. But thus far Western intellectualdom has failed to understand its roots - and no understanding, no strategy! There is no terrorism without terrorists.

\section{But why do they become terrorists?}

Recently I read in a Dutch newspaper an interview with a terrorist who said in summary: "We do not kill because we are bloodthirsty. We have no pleasure in killing people. But the jihad has to go on and someone has to shoulder the task." ${ }^{33}$ The Islamic State has become the most successful terrorist organization in history, combining State functions with a global network of extremist anti-Western, anti-democratic and anti-modern grouplets. It has a specific and (so far) particularly effective strategy to terrorize and destabilize "diabolical" society in the West, Hindu India, Christian Nigeria, Buddhist Thailand, or even any Muslim community labeled "heretic." Like previous terrorist groups, it uses the

\footnotetext{
${ }^{33}$ Vermeulen (2016).
} 
method of exacerbation, purposely causing Islamophobic reactions in order to destroy the "gray area" where (by trial and error) coexistence between Muslims and others is being built. No use trying to obfuscate the issue by declaring that ISIS militants "are not true Muslims." ${ }^{34}$ This is about as enlightening as affirming the opposite infamy, that "the Islamic State does what all Muslims dream to do." The central question is: who is attracted and mobilized to join this group and why?

Both interpretations mentioned by Roy, the Third Worldist Leftist one and the Rightist clash of civilizations, would in order to be proven, require that a majority of the world's Muslims identify with jihadism. This, however, is evidently not the case: despite their criticism of the West, the vast majority of Muslims around the world firmly rejects terrorism. ${ }^{35}$ Only a small minority radicalizes and takes up arms against the West or against those of their coreligionists supposedly "infected" by Western microbes. IS activists are usually young, relatively educated, but alienated from the society in which they live. In Europe they are young second-generation Muslim immigrants, who do not feel accepted by the surrounding Western society, and who feel discriminated against and rejected. ${ }^{36}$ This does not mean that all or even most radicalized are personally victims of oppression: more common is super-identification with the suffering of other Muslims, through television images, the Internet, and social media. Their exclusion may partly be blamed on the host society, and is partly due to cultural resistance within Muslim minorities. The values that guide life in the West's big cities - consumerism and the chase for pleasures, individual, sexual, intellectual and religious freedom - are for the new Muslim generation a permanent temptation, at once seductive and repulsive. We are talking here of a minority who no longer feels "at home" in their own society and in an increasingly incomprehensible and chaotic world that fails to offer them a meaning in life. When they commit suicide in the act of killing other young people, at a musical show or in a restaurant, do they not also kill a part of themselves: that side that desires that which they exorcise? In an important article anthropologist Scott Atran analyzes how the success of recruitment in extremist Islamist groups is explained by the answer they offer to young people in search of belonging and a meaningful ideal: the extremist vision fills emptiness of meaning that our own Western society does not know how to confront. It is the ideology of redemption and psychological fusion with a group of "peers" believing in the same ideal that generates mobilization to death, and that is the terrorist machine. Atran recalls Goebbels' and Hitler's incantatory "do you want butter or guns?", the phrase that mesmerized millions of Germans with a sacrificial vision for an ideal - more than with promises of prosperity. ${ }^{37}$

The jihad is a revolution and, as Atran emphasizes, every revolution is a moral event. Young Muslims who leave to join the Islamic State in Syria as well as those who stay in

\footnotetext{
${ }^{34}$ Ahmad (2015).

${ }^{35}$ Esposito and Mogahed (2008).

${ }^{36}$ Cf. Kepel (2015).

${ }^{37}$ Atran (2015).
} 
the West to obey its call for bringing jihad home, do not sacrifice lives (their own and that of others) out of selfishness but on behalf of an ideal. The Islamic State functions here as a sort of Islamist Zion, a guiding country that is at once ideal, inspiration, and source of emulation. To identify at the root extremism such a lack of a credible ideal means to point at a fundamental weakness in modern society in general - and that is something that goes beyond the specific problematic situation of Muslim youth, and of the other growing cohorts of excluded. In the West, a hyper-individualistic democracy, post-Christian and post-socialist, obsessed by the search for material means and by hedonism, has failed to respond to the lack of ends, of meaning, purpose, and transcendence. It suffers from a lack of mobilizing "ism". It is of course easier to bomb the Islamic State in Syria and Iraq than to integrate through a new vision, the West's own alienated at risk of radicalization. But this second strategy would be more effective against terrorism.

The radicalized minority of young Muslims engaging in jihadi terrorism can also count on a social periphery, a potential fifth column of alienated and radicalizable supporters who might detach themselves from their families and communities and join in their turn the ranks of jihadism. The risk is not limited to the Muslim community. Alongside the specific group of second generation Muslims, one encounters among jihadists a very high rate of converted of European descent. Unless challenged by an alternative and more convincing utopia, jihadi idealism at war against secular modernity may affect many other Muslims and non-Muslims.

Both the post-colonial global context and intra-religious issues doubtless play their role in the genesis of terrorism. However, as Roy remarks, in the first place "we are dealing not with the radicalization of Islam but with the Islamiation of radicalism." ${ }^{38}$ In other words, the attraction of terrorism is explained less by Islam as a religion than by the weakening of other radical ideologies such as the extreme Left, which has left Islamism "prevalent in the radical market." The same young idealists who one generation ago gravitated to the Red Brigades or Che Guevara, are today absorbed by jihadism. Might Muslim minorities in the West fuse with other excluded alienated groups to eventually replace the proletariat as the famous lost subject of emancipation ${ }^{39}$

\section{Conclusion: The task of the intelligentsia}

At the start of this article I asked if public intellectuals have contributed strategic proposals to combat terrorism. Unfortunately, we are forced to conclude that the answer must be a qualified "no". If we understand today quite a lot about terrorism, then we owe it more to generally un-glamorous scholars who find little echo in popular media.

The mystique of jihad as an ideal for a significant portion of young Muslims helps us to

\footnotetext{
${ }^{38}$ Roy, op. cit., p. 16.

${ }^{39}$ Cf. Keucheyan (2013).
} 
understand the impotence of many intellectuals no less than the impetus of terrorism proper. After all, reflecting on ideas and ideals for society, and eventually developing new ones, is the task par excellence for public intellectuals. The same mystique also suggests how public intellectuals might go about answering the challenge. The terrorist - anarchist or nationalist yesterday, religious fundamentalist today - exerts his fascination on certain intellectuals precisely because he dares to act on his idealism. This fascination is similar to the one he has on his own followers. In every jihadist there is also a bit of the public intellectual, but one who does not only pontificate but acts. In the conjuncture of lack of ideological alternatives, the task of our intellectuals is to make explicit and reject this underground correlation, and to develop a new ideal that can replace the attraction of terror. Trying to do so, however, they must face the challenge of credibility. Terrorists are among those who apply what they preach, and whose practice reflects their theory. Political, religious and intellectual leaders gain credibility to the extent they are willing to suffer for their convictions, and "walk their talk". To the extent that they do not, they unmask themselves as opportunists, clowns or criminals. This equation was as valid for Trotsky, Gandhi, Mandela or Martin Luther King as for Hitler and Osama bin Laden. In this sense suicide bombers are the supreme ideologues and their martyrdom, the most unbeatable propaganda. Unfortunately, in the question of assuming the personal costs of their public positions, the history of many intellectuals leaves much to be desired.

\section{BIBLIOGRAPHY}

AFARY (Janet) and Kevin B. Anderson, Foucault and the Iranian Revolution: Gender and the Seductions of Islamism. Chicago and London, 2005.

AHMED (Nafeez Mosaddeq), "ISIS wants to destroy the 'grey zone'. Here's how we defend it." in: OpenDemocracy 16 November 2015. https://www.opendemocracy.net/nafeezahmed/isis-wants-destroy-greyzone-how-we-defend ATRAN (Scott), "ISIS is a revolution." 15-12-2015. in: https://aeon.co/essays/why-isishas-the-potential-to-be-a-world-altering-revolution BAUDRILLARD (Jean), The spirit of terrorism. New revised edition. London and New York: Verso, 2003.

BERWICK (Andrew), 2083: A European declaration of Independence. London, 2011. CHOMSKY (Noam) and Edward S. Herman, The political economy of human rights (1979). CHOMSKY (Noam) 19-1-2016 "Noam Chomsky Slams West's Charlie Hebdo Outrage: 'Many Journalists Were Killed by Israel in Gaza Too'.' in: http://www.alternet.org/media/ noam-chomsky-slams-wests-charlie-hebdo-outrage-many-journalists-were-killed-israelgaza-too

ESPOSITO (John L.) and Dalia Mogahed, Who Speaks For Islam? What a Billion Muslims Really Think. Gallup Press, 2008.

FANON (Frantz), Les damnés de la terre. Préface de Jean-Paul Sartre (1961). Paris: La 
Découverte, 2002 (1961, 1st).

FARIAS (Victor), Heidegger and Nazism, Temple University Press, 1989.

GRAY (John), Al Qaeda and What it Means to be Modern. The New Press, 2005.

HOFFMAN (Bruce), Inside Terrorism. New York: Columbia University Press, 1998.

HONDERICH (Ted), After the terror. Montreal : McGill-Queen's University Press, 2003.

HUNTINGTON (Samuel), The Third Wave: Democratization in the Late Twentieth Century.

University of Oklahoma Press, 1991.

HUNTINGTON (Samuel), “The Clash of Civilizations?” in: Foreign Affairs 7,3 (summer 1993) pp. 22-49.

IGNATIEFF (Michael), The lesser evil: Political ethics in an age of terror. Princeton and Oxford: Princeton University Press, 2004.

JACOBY (Russell), The last intellectuals: American culture in the age of academe. New York: Basic Books, 2000 (1987, 1st).

KEUCHEYAN (Razmig), The Left Hemisphere: Mapping Critical Theory Today. London and New York: Verso, 2013.

LEWIS (Bernard), The crisis of Islam: Holy War and Unholy Terror. (2003)

LILLA (Mark), The reckless mind: Intellectuals in politics. New York: NYRB, 2001.

MAMDANI (Mahmood), Good Muslim, Bad Muslim: America, the Cold War, and the Roots of Terror (2005).

MESTROVIC (Stjepan G.), Anthony Giddens: The last modernist. London and New York: Routledge, 1998.

NUSSBAUM (Martha), “Veiled threats?”. In: New York Times 11-7-2010.

POSNER (Richard), Public intellectuals: A study of decline. Cambridge, MA and London:

Harvard University Press, 2001.

ROY (Olivier), "Une revolte générationelle et nihiliste”. in: (Le Monde Hors-Série JanvierMars 2016), Djihadisme: 100 pages pour comprendre. Pp. 14-17. (artigo original em Le Monde de 24-11-2015: http://www.lemonde.fr/idees/article/2015/11/24/ledjihadisme-une-revolte-generationnelle-et-nihiliste_4815992_3232.html)

SCHMID (Alex), Jongman et al., Political terrorism: a new guide to actors, authors, concepts, data bases, theories, and literature. Amsterdam: Transaction Books, 1988. SOWELL (Thomas), Intellectuals and society. New York: Basic Books, 2009. TODD (Emmanuel), Qui est Charlie ?: Sociologie d'une crise religieuse. Paris: Seuil,|2015. VERMEULEN (Margreet), "Het brein van de terrorist" (The brain of the terrorist). in: De Volkskrant (Amsterdã) 23 January 2016, p. 41.

WALZER (Michael), Just and unjust wars: A moral argument with historical illustrations. New York: Basic Books, 1992 (1977, 1st). WOLIN (Richard) (Ed.), The Heidegger controversy: A critical reader. Cambridge and London: MIT, 1998 (1993, 1st).

ZIZEK (Slavoj), "Foreword: The Dark Matter of Violence, Or, Putting Terror in Perspective." In: Wahnich (Sophie), In defense of the terror: Liberty and death in the French Revolution. New and London: Verso, 2012. Pp. Xi-xxxi. 